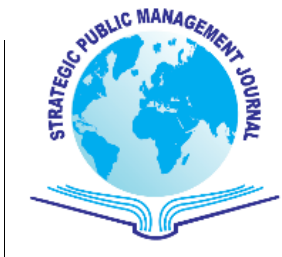

Financial Delegation system in the Context of New Public Management: Evidence from an Australian Public Sector

\author{
Yeni Kamu Yönetimi Bağlamında Mali Yetki Sistemi: \\ Avusturalya Kamu Sektörü Deneyimi
}

Anup Chowdhury ${ }^{1}$

Nikhil Shil ${ }^{2}$
Strategic Public Management Journal Volume 5, Issue 10, pp. 01-11 December 2019

DOI: $10.25069 /$ spmj.562734

(C) The Author(s) 2019 For reprints and permissions: http://dergipark.gov.tr/spmj

\begin{abstract}
This paper contributes to the study of financial management in public sector organization in the context of New Public Management (NPM). It deploys an earnest attempt to explore the financial delegation system in the context of NPM initiatives in Australia. A government department in the Australian Capital Territory has been adopted as the field for investigation. The nature of the present research is explorative and the focus of this research is to study in depth of a particular phenomena. Qualitative research methodology was chosen to obtain a better understanding of the phenomena. Case-based research method was used in developing a fuller understanding of the relative role of financial delegation system in the management of organisational performance. In this study, data collection involved a triangulation approach and the three sources were archival records, interviews and observation. As financial delegation system is socially constructed, Giddens' structuration theory was adopted in this research to obtain a better understanding of human actions and to explore how these control devices are implicated in the wider social context through time. Empirical evidence from the field supported that the selected researched organisation has adopted a wide range of financial delegation mechanisms within the organization. The research also demonstrated that the implementation of financial delegation system in the selected organization is the function of NPM in the key areas of financial management. These findings are consistent with the view that NPM promotes a culture of performance in Australian public sector.
\end{abstract}

Key Words: Public sector, new public management, financial delegation, case study, structuration theory

\title{
INTRODUCTION
}

During the 1970s a variety of factors influenced public sector organisations to depart from the original developmental goals set for the public organizations. They have mostly been assigned specific financial objectives similar to those in the private sector. In this context the practitioners started to adopt new management approaches as the basis for improving performance in the public sector (Metcalfe and Richards, 1992; Osborne and Gaebler, 1992; Hughes, 1995; Girishankar, 2001; Robbins, 2007; Christiaens and Rommel, 2008; Broadbent and Guthrie, 2008; Alam and Nandan, 2008; Dooren et al., 2010; Walker and Boyne, 2010; Hoque and Adams, 2011). The new management approach has been based on the premise that the efficiency and effectiveness of the public sector organisations could be improved through the introduction of private sector management techniques (Painter, 1988; Hood, 1995; Tooley, 1999; Parker and Bradley, 2000; Atreya and Armstrong, 2002; Crawford et al., 2003; Christensen, 2005; Cohen et al., 2007; Alam and Nandan, 2008; Bouckaert and Halligan, 2008; Berry et al., 2009; Christensen and Parker, 2010). More precisely this new approach is centred on NPM ideals (Hood, 1991; Dunleavy and Hood, 1994; Hood, 1995). The term 'New Public Management' is used to describe the changing style of governance and administration in the public

\footnotetext{
${ }^{1}$ Professor, Department of Business Administration, East West University, Dhaka, Bangladesh, anup@ewubd.edu

${ }^{2}$ Associate Professor, Department of Business Administration, East West University, Dhaka, Bangladesh, nikhilacc@yahoo.com
} 
sector. The most definitive characteristic of the NPM is the greater salience that is given to what has been referred to as the three 'Es'- economy, efficiency and effectiveness (Barrett, 2004). NPM is the commonly used label for the ambition of government organisations in many countries to run the public sector in a more businesslike manner (Jansen, 2004). Hood (1991) was the first to use the term New Public Management (NPM). $\mathrm{He}(1991,1995)$ explored changes in public sector financial management in a number of OECD countries over the 1980s linked to the NPM. He $(1991,1995)$ argued that NPM involved a different concept in public accountability, with different patterns of trust and distrust and hence a different style of accounting. He (1995) pointed out seven dimensions of change within this NPM and mentioned the doctrinal components of NPM which are:(1) a shift towards corporatized units; (2) a shift towards greater competition both between public sector organisations and between public sector organisations and the private sector; (3) a move towards private corporate sector management practices; (4) greater stress on discipline and parsimony in resource use; (5) more emphasis on visible hands on top management; (6) a move towards more explicit and measurable (or at least checkable) standards of performance; (7) attempts towards output control. In his doctrinal components on NPM, Hood (1995) also showed some possible accounting implications, for example: more cost centre units, identifying costs and understanding cost structures, private sector accounting norms, more stress on the bottom line, more use of financial data for management accountability, performance indicator and audit and broader cost-centre accounting. One of the major devices of NPM reform initiatives was delegation, specifically, financial delegation. Financial delegation system under new public management focuses on strategic planning on public spending and it is considered as one of the major apparatus of expenditure management in the public sector. It promotes result-oriented management and ensures accountability and efficiency.

The Australian public sector has been seen to move from an ethos of public sector administration to public sector management (Hawke, 1990; Halligan and Power, 1992; Wanna et al., 1992; Parker and Guthrie, 1993). Public sector administration was traditionally characterized in terms of administering the legislated functions of government organisations. It was an authority-based administrative approach that was characterized by bureaucratic structure and process model originally laid down by Max Weber. Over the last decade in the Australian public sector, this approach has been supplanted by the managerialist model with a focus on outputs (Parker and Guthrie, 1993; McKay, 2003; McPhee, 2005; Halligan, 2009). Dixon and Kouzmin (1994) also observed that Australia has gone through a process of radical change from the early 1980s. They (1994) observed that in 1980s the public agencies were not able to meet the contemporary community needs and as a result the reforms emerged. They mentioned that the objective of these reforms was to make public managers more accountable for their activities and more efficient and effective in their use of resources. In order to ensure improved service delivery to citizens and the attainment of desired results and outcomes the Australian government developed financial delegation principles which contributes to effectiveness and efficiency with no delays in service delivery. Financial delegation principles ensure effective financial management is in place and safeguard its financial resources. This policy document is an integral part of the financial governance model in the Australian public sector

\section{THE RESEARCH QUESTION}

Berry et al. (2009) found that during the last two decades, the concept of 'new organisational forms' has gained currency and transformation is more prevalent in some sectors, specifically in the public sector. In the light of reforms in the Australian public sector over the last thirty years, this study is about the exploration of financial delegation system in the context of New Public Management (NPM) initiatives. A government department, in the Australian Capital Territory (ACT) has been adopted as a field of investigation for the purpose of this exploration. The study will seek answers of the following research questions:

How has financial delegation system become embedded in the managerially oriented selected researched public sector organisation? Specifically,

(a) How has the researched organisation adopted financial delegation system within their organization?

(b) In what ways are financial delegation system linked to the organisational actions of the researched organization? 
(c) How has financial delegation system contributed to and shaped new organisational culture within the researched organisation?

\section{RESEARCH METHOD AND DATA COLLECTION}

This research explored in depth the evolution of financial delegation system in the context of new public management initiatives in Australia. A governmental department in the Australian Capital Territory was selected for the purpose of the exploration. The qualitative research approach was adopted and data was collected in the case study tradition. By using qualitative research methodology, this study is something like naturalistic inquiry (Guba and Lincoln, 1981) which has provided a thick description (Geertz, 1973) of the context under consideration. The main data sources were archival official documents and interviews. The epistemological position influenced the researcher to conduct interviews because it allows a legitimate or meaningful way to generate data by talking interactively with people, asking them questions, listening to them, gaining access to their accounts and articulations, or analyzing their use of language and construction of discourse (Mason, 2002). The primary interview method used in this study was unstructured and open-ended. In this study snowball sampling technique was used. This technique identifies respondents who are then used to refer researchers on to other respondents. The interview proceedings were tape recorded with the consent of the participant. For safety reasons, back-up notes were also taken and checked and compared when the transcriptions were made. The interview tapes were transcribed later word for word. Key interview transcripts were fed back to the respective interviewees to establish the validity of the interview data. In addition, the researcher used direct observation to supplement and corroborate the archival documents and interview data. In qualitative inquiry, data collection is not an end. It requires analysis, interpretation and presentation of findings (Patton, 2002; Irvine and Gaffikin, 2006; Merriam, 2009; Nagy et al., 2010). In this study, the researcher analyzed data using the approach provided by Miles and Huberman (1994) which includes data reduction, data display and conclusion drawing and verification.

\section{THEORETICAL FRAMEWORK FOR THE STUDY}

Llewelyn (2003) observed that qualitative research using interpretive methodologies now has become increasingly influential. According to these methodologies, financial delegation system is not a natural phenomena, they are socially constructed and they can be changed by social actors (Ryan et al., 1992). In order to gain a better understanding about the control systems in an organisation, it is necessary to look at the relationship between day-to-day social action and the various dimensions of social structure. The present study has adopted Giddens's structuration theory to understand how financial delegation system, one of the important management control systems, is implicated in their social setting. Here, it is assumed that multiple realities can exist in a given situation and for this reason the intention of the research is to promote a subjective research.

Giddens (1979: 64) claimed that every social system has structures. Structure refers to the structuring properties which are the 'rules and resource, recursively implicated in the reproduction of social systems' (Giddens, 1979: 64). Giddens et al. (2011) argued that social structure is not like a physical structure, such as building, which exists independently of human actions. Giddens et al. (2011) further argued that human societies are always in the process of structuration. They are reconstructed at every moment.

In a social setting, actors produce and reproduce structures but at the same time are also guided by them. Giddens $(1976,1979$, and 1984) identified that structure in its conventional sense as referring to the structuring properties of any social system. Structures are the codes, rules, blueprints or formulas that shape social behavior. Agency, in contrast, depicts social life as actively constituted by individuals who subjectively produce shared understandings which guide them in social setting.

Giddens (1979) suggested that within the processes of structuration there are three dimensions of social structure: signification (meaning), domination (power) and legitimation (morality). Signification is the rules or aspects of rules. These are codes or modes of coding. Domination involves authorization and allocation. Legitimation is the modes of normative regulation. When people act, they draw from these structures. Agents in their actions constantly produce and reproduce the social constructs and Giddens mentioned that all human interaction is inextricably composed of structure of meaning, power and moral framework. These three 
dimensions are only analytically separable properties of structures (Giddens, 1979: 97) and are inextricably linked in reality.

In every dimension there are modalities through which interactions are made and the main processes of human action during interaction are: communication, the exercising of power and sanctioning of conduct.

\section{FINDINGS OF THE STUDY}

Financial delegation is an integral part in the new accounting based signification structure at the researched Department (Giddens, 1979; 1984). The selected researched Department has implemented financial delegation system in line with NPM ideals which ensure that adequate controls emphasizing outcomes and results are in place. To achieve the best result, the Department has established financial delegation which is different from the private sector.

According to the Financial Management Act 1996 (ACT, 1996) of the ACT the Chief Executive of the Department is responsible for the efficient and effective financial management. The Department's documents revealed that to achieve cost efficiency and better result, the Chief Executive issues financial instructions to its staff and managers of the department. The objective of this instruction is to establish an appropriate internal control and accountability framework within the department and to ensure financial results at the end of each year which is in accordance with the department's plan and the government's budget.

Financial delegation of the department is also intertwined with domination structures (Giddens, 1979; 1984). In the Department, it is evident that operational managers are accountable to the executives for their spending. This enables the executives to exercise power over the operating units and viewed as the medium for the domination of operating managers (Giddens, 1979; 1984). During an interview, one of the mid-level executives in the Finance Division illustrated this point:

We have proper financial procedures and guidelines. We have financial delegations. These delegations are based on positions so it doesn't matter what your level is within the organisation. Financial delegation comes from the Chief Executive. So, we manage the whole process that has to be approved by the Chief Executive before it becomes valid. Every year when audit comes around some of the things to look at are the people on the right delegation or not.

The ACT Government Financial Management Act 1996 (ACT, 1996) allows the Chief Executive to provide authority to managers to incur costs. In establishing a results control system, this cost is limited by the budget delegated to each manager. This limit is a reflection of macro resource control of Financial Management Reform Program in the Australian public sector. Interviews with participants in this study indicated that for the efficient and effective financial management of the department, this delegation is necessary. Delegations are directed at positions rather than at individuals. The following representative comment made by a senior executive of the department supported this view:

Financial delegation is part of our accountability framework and that delegation is authorized through legislation where decisions have to be made by people who are capable of making those decisions. We work under our budget and we have a list of delegation under the Financial Management Act.

Organisation documents also suggest that no manager is permitted to approve her or his own personal expenses, or any expenses in which the manager has a conflict of interest. The department uses this control mechanism to control the actions of the employees (Neely et al., 2005; Malmi and Brown, 2008). The Strategic and Organisational Finance Team of the department needs to be advised on any individual purchases equal or over $\$ 50,000$. The department follows the ACT Governments Procurement Guideline for purchasing and contracting. It ensures that best value for money is obtained. Only designated managers may approve expenses and relevant managers may instruct the purchasing staff in completing the purchasing functions. It is a requirement that managers must advise the Financial Controller of all significant contracts, and related cash requirements, to assist with cash forecasting and funding which is equal or greater than $\$ 50,000$. 
Giddens' structuration theory is concerned with the relationship between the actions of agents and the structuring of social systems in the production, reproduction and regulation of social order. In the Department, the role played by actors and their interaction with the structure and social processes have been identified. In the Department, the financial delegation is viewed as an authoritative resource in the hand of the senior executives and to exercise power which facilitates the transformative capacity of action. A review of Department's documents support the researcher's finding that to exercise authoritative power, the department has implemented a number of control mechanisms on financial delegations which are discussed in the next sub sections.

\subsection{Control of Payment of Accounts}

For the payment of accounts, the Department follows the ACT Accounting Policy Manual. The Department pays its accounts according to the contractual arrangements and if no contractual arrangements are specified, department follows ACT Government standard payment terms. It is quite different from the private sector as public sector deals with public money. The Department generally pays within 30 days from acceptance of goods or services and the receipt of a correctly rendered invoice. Payment of all invoices received in a given month must be made by the $25^{\text {th }}$ of the following month otherwise the Department is bound to pay interest on those amounts.

The Department uses different alternatives for its payments. The mode of payments made by check, utilizing credits on suppliers' account, by credit card and direct credit by electronic fund transfer. For the credit card statement finance managers are responsible for the reconciliations. If there is any mis-reconciliation it is the relevant manager's responsibility to ensure that the payments are recorded on the relevant accounting system. The Department encourages its managers to avail suppliers discount for earlier payments also. In addition to payment to suppliers the Department has a policy on management of accounts receivable system. This is explored next.

\subsection{Control and Management of Accounts Receivable System}

In order to manage the net costs within budget and to optimize net cash flows and working capital management, the Chief Executive is responsible for ensuring all monies due to the Department are received in a timely manner. It is also the Chief Executive's responsibility to ensure that incidence of bad debts is avoided or minimized. It was one of the major issues related with the financial management reforms in the Australian public sector. The Department has developed their Accounts Receivable management system like the private sector. The Strategic and Organisational Finance Team developed appropriate accounting systems and records which provides a complete and accurate audit trail of the activities of each debtor account. Review of Department's documents attest to the observation that it is the department's Financial Controller's responsibility to ensure that adequate controls are in place to prevent the recording of receipts, which are not based on actual payments by debtors.

To establish this control mechanism, the Department has also established segregation of duties like private sector, which includes: system access to creation and deletion of debtor accounts, receipting of moneys, recording/ posting of amounts received and functions of the manager responsible for the bank account, including bank account reconciliations. The financial systems administrator is responsible for ensuring that adequate controls are in place within systems and procedures to enable the prevention of duplicate receipts, overdue accounts, and crediting of receipts to the wrong debtor account.

The Department has established a policy for recovery and management of debtors. It is a preventive type of management control system. Managers of the relevant areas are responsible for ensuring the appropriate procedures are in place for pursuing, monitoring, control and collection of debtors accounts. Organisational documents suggest that the Department has set a time frame and performance target for collection of debtors. The Department's documents suggest that every two months, managers report to their immediate supervisor about the collection of debtors. They follow the same practice if the debtor is another public sector organisation. The collection report includes an explanation of any variance under and over against performance targets and details of correction action. If the accounts are not paid within 30 days staff undertakes appropriate recovery 
procedure. If an account is overdue for 90 days the matter is referred to the Financial Controller. The Financial Controller takes necessary initiatives which may be the sale of the debt to a debt collection agency, or refer it to the ACT Government Solicitor. At the final stage the Financial Controller can write off the debt. However, this action needs to be reported to the Chief Executive each six months. Another component of financial delegation is banking and cash management. This is presented next.

\subsection{Control of Banking and Cash management}

In the public sector, payments are frequently not made on time and revenue is often collected late (Shand, 1995; Vickland and Nieuwenhuijs, 2005; Annessi-Pessina and Steccolini, 2007; Ter Bogt, 2008). To overcome this problem and to achieve desired results the Department has established an effective banking and cash management system. The Department's banking and cash management system is presented in Figure 1. Field study data revealed that the staff of the Department might deal with four different types of money. These are: The Department's own cash which are related with the production and supply of outputs, cash collected on behalf of other agencies. This is what is different from, the private sector. The government's cash which are related with the expenses incurred and revenues collected on behalf of the Territory and private monies which the Department holds as a trustee.

Figure 1: Control of Banking and Cash Management in the Researched Organization

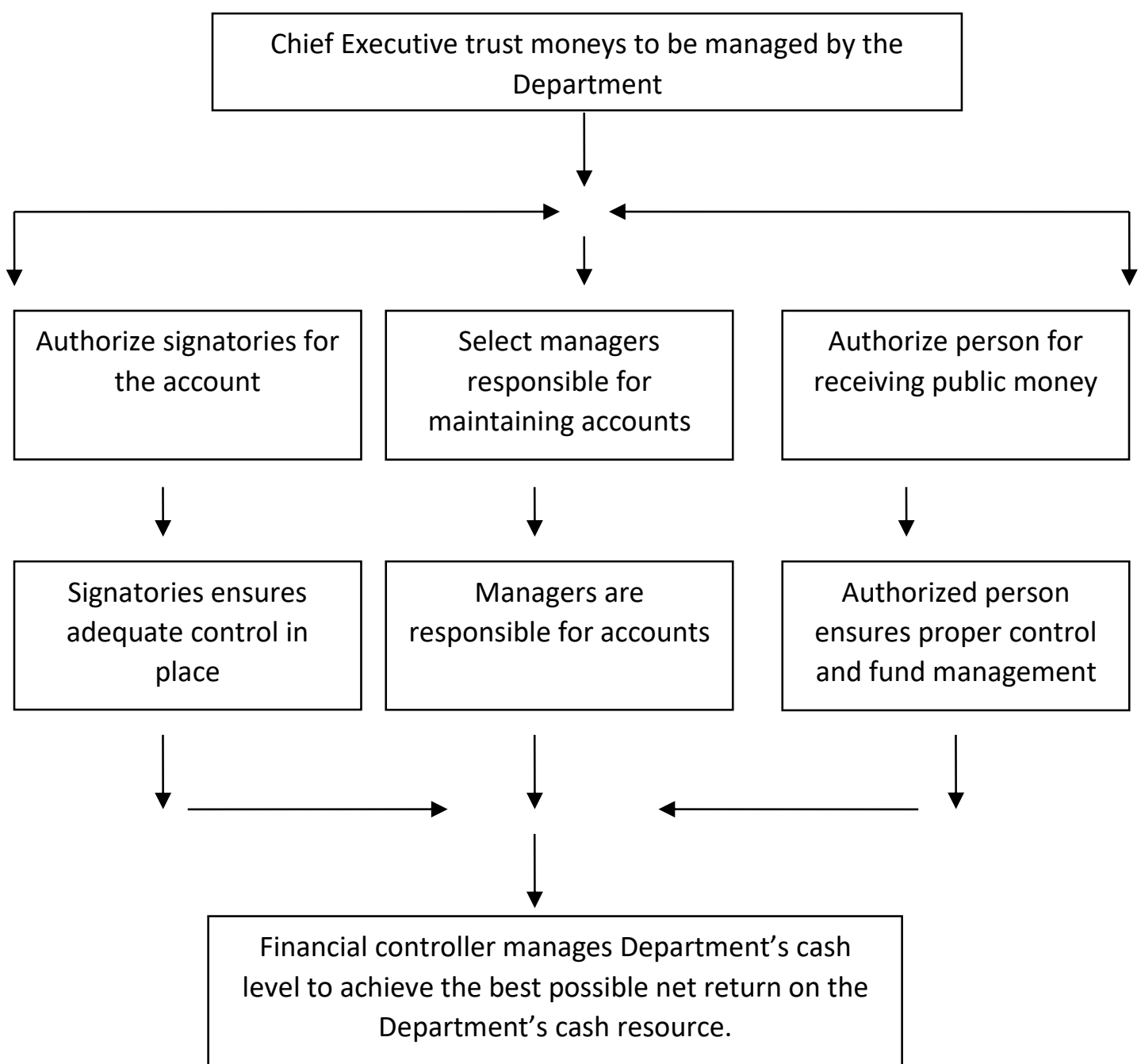

Source: Department's Chief Executive's Financial Instruction 
Only the Chief Executive has the power to open a bank account for public or trust moneys to be managed by the department. The Chief Executive also authorizes the signatories for the account and selects the managers responsible for maintaining the accounts. It is the bank account signatories' responsibility to ensure that adequate controls are in place and only authorized payments are presented to them for sign-off. Managers who are responsible for maintaining bank accounts prepare bank reconciliation statements at least once in a month. It is the Financial Controller's duty to manage the Department's cash level to achieve the best possible net return on the Department's cash resources.

The Department controls electronic fund transfers (EFT) in the same way like manual transactions. The Department established appropriate control systems and manual links between the bank's system and Department's accounting system.

The Chief Executive appoints and authorizes person for receiving public moneys. It ensures proper control and management of funds. The Financial Controller has the power to authorize new methods and changes to existing methods of receipting. It requires automated posting of deposits into the Department's bank account. However, before adopting those methods, qualified accountant and auditor tests and reviews them. It is the relevant area managers' duty to ensure adequate security of all public money under their care and custody they have also to ensure that controls are in place.

To maintain proper financial delegation, the department has established an effective control mechanism on its internal expenses also. One of them is official hospitality. That is explored next.

\subsection{Control of Official Hospitality}

The department has implemented a strict control mechanism on official hospitality. Official hospitality means expenditure for entertainment, meals, liquid refreshments, flowers and small gifts provided to non ACT government officers (DHCS, 2007a). Field study data revealed that the Department has issued a corporate governance policy on official hospitality which is different from the private sector. According to this policy official hospitality must obtain approval of the Chief Executive prior to the event. It is a new signification dimension (Giddens, 1979; 1984) in the public sector. As a general principle, public money should not be used to provide hospitality for ACT government officials. However, the Chief Executive may establish an official hospitality fund if it is essential for the efficient conduct of public business. The types of activities which meet the definition of official hospitality and for which approval for expenditure may be sought are: refreshments provided during or at the completion of interstate meetings, provision of meals or refreshments for visiting international or industry officials, working meals with non ACT government officers, official functions such as dinners, lunches and official receptions provided to visiting overseas dignitaries, a gift to a person (other than non ACT government officer) as an appropriate gesture of appreciation for the performance of a nonremunerated service or to a visiting international dignitary (DHCS, 2007a).

\subsection{Control of Corporate Credit Cards}

Using credit cards in government purchasing and in the payment of government accounts was a major discussion in Australia. It reduces the cost of paper processing and provides an excellent audit trail in the case of any possible errors, or fraud or abuse (Shand, 1995; Goyal, 2008; Telyukova and Wright, 2008; Bertaut et al., 2009; Massoud and Scholnick, 2011). However, they may tempt to some people to misuse them. If it is properly dealt within the organisation it can be an effective control mechanism.

The Department issues corporate credit cards where there is a demonstrated need to process frequent low value purchases. The term 'low value' means transactions that are less than $\$ 2,000$ (inclusive of GST). These transactions include travel and accommodation, training courses and procurement of minor supplies or office requisites (DHCS, 2007b). Card uses reduce the administrative costs and time involved in processing and paying accounts by check or direct credit. The Strategic and Organisational Finance Team of the Department issues corporate credit cards and it requires approval by the Chief Executive. 


\section{CONCLUSION}

The financial delegations explored in this study are related with the notion of 'value for money' or directly related to results in the public sector. Evidence from the field showed that some of the delegations were adopted from the private sector; some of them were used on a modified basis; and some of them are unique to the Department. Boisclair (1984) stipulated that in the public sector officials are responsible for the expenditure of public funds, thus they must not only act within the relevant legal and ethical limits but must also strive to ensure that their decisions result in economical, efficient and effective public services.

\section{REFERENCES}

ACT Government (1996), Financial Management Act 1996, ACT, Australia.

Alam, M. and Nandan, R. (2008), "Management Control Systems and Public Sector Reform: A Fijian Case Study", Accounting, Accountability and Performance, Vol. 14, No.1, pp.1-28.

Anessi-Pessina, E. and Stecolini, I. (2007), "Effects of budgetary and accruals accounting coexistence: Evidence from Italian local governments", Financial Accountability \& Management, Vol.23. No. 2, pp. 113131.

Atreya, B. and Armstrong, A. (2002), "A Review of the Criticisms and the Future of the New Public Management", Working Paper, School of Management and Information Systems, Victoria University, Melbourne, Australia

Barrett, P. (2004), "Financial Management in the Public Sector- How Accrual Accounting and Budgeting Enhances Governance and Accountability", Address to the Challenge of Change: Driving Governance and Accountability, CPA Forum 2004, Australian National Audit Office

Bertaut, C. C., Haliassos, M. and Reiter, M. (2009), "Credit Card Debt Puzzles and Debt Revolvers for Self Control", Review of Finance, Vol. 13, Issue 4, pp. 657-692.

Berry, A. J., Coad, A. F., Harris, E. P., Otley, D. T., and Stringer, C. (2009), "Emerging themes in management control: A review of recent literature", The British Accounting Review, Vol. 41, pp. 2- 20.

Boisclair, J. P. (1984), "The Challenge of Comprehensive Auditing: Thriving on Value for Money", $C A$ Magazine, January, pp. 24-29.

Bouckaert, G. and Halligan, J. (2008), Managing Performance: International Comparisons, Routledge, London.

Broadbent, J. and Guthrie, J. (2008), "Public Sector to Public Services: 20 Years of Contextual Accounting Research", Accounting, Auditing \& Accountability Journal, Vol. 21, No. 2, pp. 129-169.

Christensen, M. (2005), "The Third Hand: Private Sector Consultants in Public Sector Accounting Change", European Accounting Review, Vol. 14, No. 3, pp. 447-474

Christensen, M. and Parker, L. (2010), "Using Ideas to Advance Professions: Public Sector Accrual Accounting”, Financial Accountability \& Management, Vol. 26, Issue, 3, pp. 246-266.

Christiaens, J. and Rommel, J. (2008), “Accrual Accounting Reforms: Only for Businesslike (Parts of) Governments”, Financial Accountability \& Management, Vol. 24, Issue 31, pp. 59-75.

Cohen, S., Kaimenaki, E. and Zorgios, Y. (2007), “Assessing IT as a key success factor for accrual accounting implementation in Greek Municipalities", Financial Accountability \& Management, Vol. 23, Issue 1, pp. 91111.

Crawford, L., Costello. K., Pollack, J., and Bentley, L. (2003), "Managing soft change projects in the public sector”, International Journal of Project Management, Vol. 21, pp. 443-448.

DHCS (2007a), Corporate Governance Policy on Official Hospitality, ACT, Australia 
DHCS (2007b), Corporate Governance Policy on Corporate Credit Card, ACT, Australia.

Dixon, J. and Kouzmin, A. (1994), "The Commercialization of the Australian Public Sector: Competence, Elitism or Default in Management Education?"International Journal of Public Sector Management, Vol. 7, No.6, pp.52-73.

Dooren, W. V. Bouckaert, W.G. and Halligan, J. (2010), Performance Management in the Public Sector, Routledge, London.

Dunleavy, P. and Hood, C. (1994), "From Old Public Administration to New Public Management", Public Money \& Management, July-September, 1994, pp. 9-16.

Geertz, C. (1973), The Interpretation of Cultures, Basic Books, New York

Giddens, A. (1976), New Rules of Sociological Method: A Positive Critique of Interpretative Sociologies, Basic Books, Inc., New York.

Giddens, A. (1979), Central Problems in Social Theory, The Macmillan Press Ltd., London.

Giddens, A. (1984), The Constitution of Society: outline of the theory of structuration, University of California Press, Berkeley.

Giddens, A., Duneier, M., Appelbaum, R. P., and Carr, D. (2011), Introduction to Sociology, W. W. Norton \& Company, New York.

Girishankar, N. (2001), "Evaluating Public Sector Reform: Guidelines for Assessing Country-Level impact of Structural Reform and Capacity Building in the Public Sector", World Bank Operation Evaluation Department, The World Bank, Washington.

Goyal, A. (2008), "Managing perceived risk for credit card purchase through supplementary services", Journal of Financial Services Marketing, Vol. 12, pp. 331-345.

Guba, E. G. and Lincoln, Y. S. (1981), Effective evaluation, Jossey-Bass, San Francisco.

Halligan, J. and Power, J. (1992), Political Management in the 1990's, Oxford University Press, Melbourne.

Halligan, J. (2009), "Performance and Public Management in Australia and New Zealand", International Conference of the Institute of Public Administration, Riyadh, Kingdom of Saudi Arabia, 1-4 November.

Hawke, R.J. (1990), “Challenges in public administration”, in Guthrie, J. Parker, L. and Shand, D. (eds.), The Public Sector: Contemporary Readings in Accounting and Auditing, Harcourt Brace Jovanovich, Publishers, Sydney, pp. 6-19.

Hoque, Z. and Adams, C. (2011), "The Rise and Use of Balanced Scorecard Measures in Australian Government Departments”, Financial Accountability and Management, Vol. 27, pp. 308-334.

Hood, C. (1991), “A Public Management for all Seasons”, Public Administration, Vol. 69, Spring, pp. 3-19.

Hood, C. (1995), “The New public Management in the 1980's: Variations on a Theme", Accounting, organizations and Society, Vol. 20, No.2/3, pp. 93-109.

Hughes, O. (1995), "The New Public Sector Management: A Focus on Performance”, in Guthrie, J. (ed), Making the Australian Public Sector Count in the 1990s, IIR Conferences Pty Ltd., NSW, pp. 140-143.

Irvine, H. and Gaffikin, M. (2006), "Methodological insights: Getting in, getting on and getting out: reflections on a qualitative research project", Accounting, Auditing and Accountability Journal, Vol. 19, No. 1, pp. 115145.

Jansen, E. P. (2004), "Performance Measurement in Governmental Organizations: A contingent Approach to Measurement and Management Control”, Managerial Finance, Vol. 30, No. 8, pp.54-68. 
Llewelyn, S. (2003), "Methodological Issues- What counts as "theory" in qualitative management and accounting research? Introducing five levels of theorizing", Accounting, Auditing \& Accountability Journal, Vol.16, No. 4, pp. 662-708.

Malmi, T. And Brown, D. A. (2008), "Management control systems as a package-opportunities, challenges and research direction”, Management Accounting Research, Vol. 19, Issue 4, pp. 287-300.

Mason, J. (2002), Qualitative Researching, Sage Publications Ltd., London.

Massoud, N. and Scholnick, A. (2011), "The cost of being late? The case of credit card penalty fees", Journal of Financial Stability, Vol. 7, Issue 2, pp. 49-59.

McKay, K. (2003), "Two Generations of Performance Evaluation Management Systems in Australia", Canberra Bulletin of Public Administration, Issue 110, pp. 8-20.

McPhee, I (2005), “Outcomes and Outputs: Are we managing Better as a Result?" CPA National Public Sector Convention, 20 May.

Merriam, S. B. (2009), Qualitative Research: A Guide to Design and Implementation, Jossey-Bass, California. Metcalfe, L. and Richards, S. (1992), Improving Public Management, Sage Publications, London.

Miles, M. B. and Huberman, A. M. (1994), Qualitative Data Analysis: An Expanded Sourcebook, Sage Publications, London.

Nagy, S., Hesse-Biber, Leavy, P. (2010), The Practice of Qualitative Research, Sage Publications Inc., London.

Neely, A., Gregory, M. and Platts, K. (2005), "Performance measurement system design: A literature review and research agenda", International Journal of Operations \& Production Management, Vol. 25, Issue 12, pp. 1228-1263.

Osborne, D. and Gaebler, T. (1992), Reinventing Government: How the Entrepreneurial Spirit Is Transforming the Public Sector, Addison- Wesley, Reading, MA.

Patton, M.Q. (2002), Qualitative research and evaluation methods, Sage Publications, Thousand Oaks, California

Painter, M. (1988), "Public Management: Fad or fallacy", Australian Journal of Public Administration, Vol. 47, pp. 1-3.

Parker, L. D. and Guthrie, J. (1993), “The Australian Public Sector in the 1990s: New Accountability Regimes in Motion", Journal of International Accounting Auditing \& Taxation, Vol. 2, No. 1, pp. 59-81.

Parker, R. and Bradley, L. (2000), "Organisational Culture in the public sector: evidence from six organizations", The International Journal of Public Sector Management, Vol. 13, No. 2, pp.125-141.

Robbins, G. (2007), “Obstacles to implementation of New Public Management in an Irish Hospital”, Financial Accountability \& Management, Vol. 23, Issue, 1, pp. 55-71.

Ryan, B., Scapens, R.W. and Theobald, M. (1992), Research Method and Methodology in Finance and Accounting, Academic Press Limited, London.

Shand, D. A. (1995), "Financial Management Reforms in Government: An International Perspective", in Guthrie, J. (ed), Making the Australian Public Sector in the 1990s, IIR Conferences PTY Ltd. NSW, Australia, pp. 10-14.

Telyukova, I. A. and Wright, R. (2008), "A Model of Money and Credit, with Application to the Credit Card Debt Puzzle”, Review of Economic Studies, Vol. 75, Issue 2, pp. 629-647.

Ter Bogt, H. J. (2008), "Management Accounting Change and New Public Management in Local Government: A Reassessment of Ambitions and Results - An Institutionalist Approach to Accounting Change in the Dutch Public Sector", Financial Accountability \& Management, Vol. 24, pp. 209-241. 
Tooley, S. (1999), "New Public Management and Change within New Zealand's Education System: An Informed Critical Theory Perspective", Discussion Paper Series 190, Massey University, College of Business, New Zealand.

Vickland, S. and Nieuwenhuijs, I. (2005), "Critical success factors for modernising public financial management information systems in Bosnia and Herzegovina", Public Administration and Development, Vol. 25, Issue 2, pp. 95-103.

Walker, R. M. and Boyne, G.A. (2010), "Introduction: Determinants of performance in public organizations", Public Administration, Vol. 87, Issue 3, pp. 433-439.

Wanna, J., O'Faircheallaigh, and Weller, P. (1992), Public Sector Management in Australia, Macmillan, Sydney. 